\title{
Short Communication: Restoration of seagrass Enhalus acoroides using a combination of generative and vegetative techniques
}

\author{
ROHANI AMBO-RAPPE", YAYU A. LA NAFIE, SYAFIUDDIN, STEVEN R. LIMBONG, NENNI ASRIANI, \\ NUR TRI HANDAYANI, EKA LISDAYANTI \\ Department of Marine Science, Faculty of Marine Science and Fisheries, Universitas Hasanuddin. J1.Tamalanrea Km 10, Makassar 90245, South
} Sulawesi, Indonesia. Tel./fax.:+62-411-586025, `email: rohani.amborappe@gmail.com

Manuscript received: 11 October 2019. Revision accepted: 28 October 2019.

\begin{abstract}
Ambo-Rappe R, La Nafie YA, Syafiuddin, Limbong SR, Asriani N, Handayani NT, Lisdayanti E. 2019. Short Communication: Restoration of seagrass Enhalus acoroides using a combination of generative and vegetative techniques. Biodiversitas 20: $3358-3363$. Seagrass areas have been declining in extent worldwide, with associated loss in seagrass ecosystem functions and services. Seagrass restoration is important to mitigate, halt and reverse such declines and their consequences. Generative propagation has benefits in terms of genetic biodiversity, however, survival of seagrass seedlings has often been poor especially in high energy environments. Terrestrial restoration often uses shade trees to protect vulnerable seedlings. This study aimed to evaluate the feasibility of a similar approach in the marine environment, using adult plants to protect seedlings of the tropical seagrass Enhalus acoroides (L.f.) Royle. Enhalus seeds taken from a donor bed were germinated and grown into seedlings, then planted in a location with high hydrodynamic exposure at three different densities (high, medium, and low). Adult Enhalus transplants were co-planted to provide three levels of protection: fifty (high), ten (medium), and none (no protection). Results showed that high-density seedling co-planting with high protection from adult transplants had significantly $(p<0.05)$ higher six-month survival rate compared to the other treatments. Our results indicate that, even in high energy environments, co-planting seedlings with adult transplants may combine the advantages of generative and vegetative propagation methods, promoting greater short-term effectiveness in terms of seedlings survival and growth in the restored seagrass meadows.
\end{abstract}

Keywords: Ecosystem restoration, Enhalus acoroides, seagrass seedlings, seagrass transplantation, tropical seagrass

\section{INTRODUCTION}

Seagrasses play a very important role in the coastal and marine environment, and they provide the most critical ecosystem services of any marine habitat (Costanza et al. 1997; Duarte 2000; Barbier et al. 2011; Costanza et al. 2014). Additionally, seagrasses in tropical areas especially were recently found to be effective in removing bacteria capable of causing disease in humans and marine organisms from the marine environment (Lamb et al. 2017). However, due to various natural and anthropogenic factors, there has been an on-going decline in the extent of seagrass areas, and thus their associated ecosystem functions and services, from which tropical seagrasses have not been exempt (Short and Willy-Escheverria 1996; Orth et al. 2006a; Waycott et al. 2009). Seagrass conservation and restoration are urgently needed to prevent further declines and their consequences (Unsworth and Cullen 2010; Selig et al. 2014).

Over the past three decades, seagrass restoration has been implemented using a variety of techniques. Transplantation has been, and still is, the main technique used, where vegetative stocks (pieces of mature seagrass) are taken from a donor site and planted at the restoration site (Phillips 1980; Fonseca et al. 1998; Calumpong and Fonseca 2001; Bourque and Fourqurean 2014; Williams et al. 2017).

In the long run, there are concerns that transplantation will lead to genetic uniformity at the restoration sites, leading to a reduction in seagrass genetic variation (Williams and Orth 1998). This could potentially result in reduced growth, seed production, and germination (Orth et al. 2006b), and negatively affect seagrass resilience to climate change (Kendrick et al. 2012). On the other hand, the use of generative methods (direct planting or broadcasting of seeds into the field substrate; germination of collected seeds and planting the seedlings directly into substrate in the field) in seagrass restoration is still limited (but see Orth et al. (2006c); Marion and Orth (2010); Statton et al. (2013); Alagna et al. (2015) for sub-tropical and temperate seagrasses, and Ambo-Rappe and Yasir (2015) for tropical seagrass), but could provide a viable alternative to transplantation of vegetative transplants. The development and use of generative restoration techniques should be a priority, especially for seagrasses that produce seeds in large quantities. These seeds can readily be harvested and stored, and in addition, the harvesting of seeds is less damaging to the donor site than taking adult plants (Orth et al. 2006b; Ambo-Rappe and Yasir 2015).

Different degrees of success have been achieved, depending on the seagrass restoration methods used (Paling et al. 2009). Very low transplant survival rates reported 
from many seagrass transplantation projects, especially in Europe, are thought to be due to physical oceanography factors, herbivory, and competition with and/or covering by macroalgae (Cunha et al. 2012). In specific cases, physical oceanographic parameters have been observed and identified as the main factors affecting transplant survival; for example current speed and depth (van Katwijk and Hermus 2000), and substrate condition (Alagna et al. 2015). Low survival rates when using generative techniques, on the other hand, have been caused by high failure rates in seed growth in the natural environment, due to the unsuitability of environmental conditions or seed predation (Orth et al. 2002; Nakaoka 2002; Orth et al. 2007). Therefore, site suitability assessment has been considered as an important step in selecting a potential restoration site for successful mass-scale seagrass restoration (Thom et al. 2018).

The survival of seagrass propagules, whether transplants, seeds, or seedlings, seems to be largely dependent on their ability to withstand unfavorable environmental conditions, especially wave action and substrate movement. Some researchers have presented methods to provide protection to the transplants or seedlings at the restoration site, in order to increase their survival. Planting density is one parameter that could affect the survival of these seagrass propagules. Bos and van Katwijk (2007) found high transplant survival in a highdensity unit under high and intermediate levels of hydrodynamic exposure. They also observed higher survival of transplants near mussel beds, which might be due to protection from wave action provided by the mussel bed. Lee and Park (2008) used shells as anchoring devices for eelgrass transplants in order to fix the shoots in the sediment, and enable successful establishment to occur. Various anchoring devices have been introduced to improve the effectiveness of seagrass transplantation techniques (reviewed in Fonseca et al. 1998).

The main purpose of the experimental study reported here was to evaluate the benefit of combining two methods of seagrass Enhalus acoroides (L.f.) Royle restoration (vegetative and generative) in enhancing the survival of seagrass propagules used for restoration, based on the rationale that the vegetative transplants could act as effective protectors for the seedlings.

\section{MATERIALS AND METHODS}

\section{Growing seeds to seedlings}

Fruits of the seagrass Enhalus acoroides were collected from Barrang Lompo Island, Spermonde Archipelago, South Sulawesi, Indonesia $\left(5^{\circ} 02^{\prime} 43.7^{\prime \prime S}\right.$ and $119^{\circ} 19^{\prime} 37.2^{\prime \prime E}$; Figure 1) in early June 2015 . This island is surrounded by multispecies seagrass meadows dominated by E. acoroides, mostly along the western side of the island, spreading somewhat round the north and south end (Ambo-Rappe and Yasir 2015).

Fifty mature E. acoroides fruits were collected, each containing 6-10 seeds. The diameter of the seagrass seeds used ranged from 1.3-2.1 cm with an average of $1.6 \pm 0.1$ $\mathrm{cm}$. Uniform seed diameter is necessary to control for the effect of seed size on seedlings growth (Ambo-Rappe and Yasir 2015).

The seeds were detached from the fruit and planted in seed bags (black polybag, diameter $=10 \mathrm{~cm}$, depth $=15$ $\mathrm{cm})$ filled with marine sand. The bags were then placed in a tank (base area $3 \mathrm{~m} \mathrm{x} 2 \mathrm{~m} \times$ height $1 \mathrm{~m}$ ) filled with seawater to a depth of about $0.75 \mathrm{~m}$ and equipped with an aerator. The seeds were allowed to germinate and develop into seedlings. After ca. 3 months, when the seedlings had attained a leaf length of approximately $250 \mathrm{~mm}$ and developed 1-2 thin roots that could penetrate into the substratum, the seedlings were planted out in the marine environment at the experimental study site.

\section{Experimental design}

The experiment was performed in the shallow waters (50-150 cm depth) around Badi Island, Spermonde Archipelago, South Sulawesi, Indonesia (4 ${ }^{\circ} 57^{\prime} 56.4^{\prime \prime S}$ and $119^{\circ} 17^{\prime} 16.6$ "E; Figure 1), a small island surrounded by coral reefs. The island is situated in the outer middle zone of the Spermonde Archipelago and is relatively exposed to the open ocean and the influence of oceanic swells (Cleary and Renema 2007). The experiment began in midSeptember 2015, when 24 rectangular plots $(60 \mathrm{~cm} \times 40$ $\mathrm{cm})$ made from PVC piping, were submerged and stabilized on the sea bed using iron pegs driven into the sediment at each corner.

The design comprised three seedling and transplant density treatments with eight replicates $(n=8)$. The first was a high density (25 seedlings) and high protection (50 transplants) treatment (Figure 2.A); the second was a medium-density (10 seedlings) and medium protection (10 transplants) treatment (Figure 2.B); the third was a low density (5 seedlings) and no protection ( 0 transplants) treatment (Figure 2.C).

\section{Seedling survival and growth}

Subsequent to planting, the experimental plots were monitored every two weeks over a six month period. To obtain survival data, the number of seedlings and adult transplants in each plot were counted at the end of the experiment. Seedling growth was measured as longitudinal leaf length, beginning in week 10, when leaves from the nursery period were no longer observed and it could be assumed that the seedlings would have grown totally new leaves. The length of the leaves was considered an indicator of seedling conditions. Five seedlings were haphazardly sampled in each plot. All of the leaves on each seedling were measured. For each plot, leaf length was averaged across all the leaves of the 5 sampled seedlings. This average of $n=5$ seedlings was the response variable in the analysis of variance. The experimental plots were revisited for nearly two years (22 months) after the end of the experimental period. A surviving seedling was sampled; leaf length and width, number of roots, and root length were measured. 


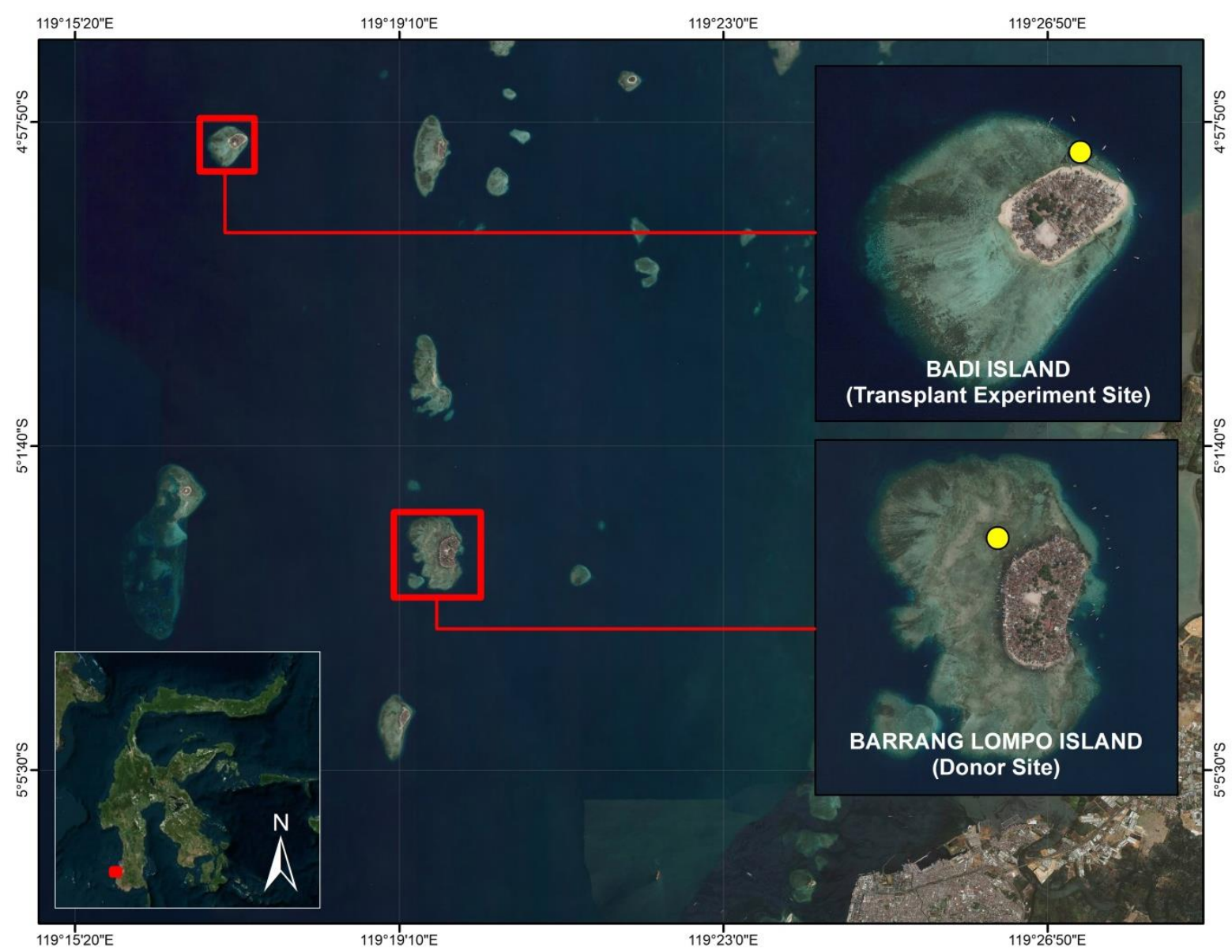

Figure 1. A map of study site in Spermonde Archipelago, South Sulawesi, Indonesia showing a donor site in Barrang Lompo Island and a transplantation experiment site in Badi Island

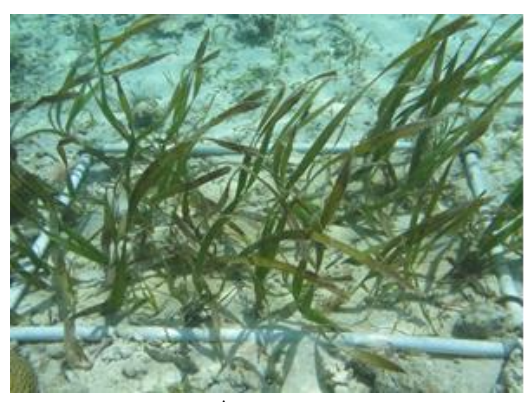

A

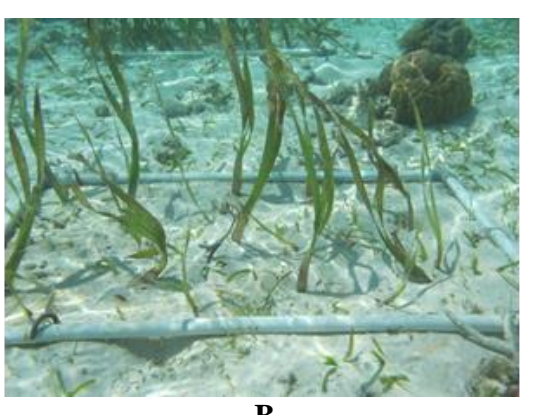

B

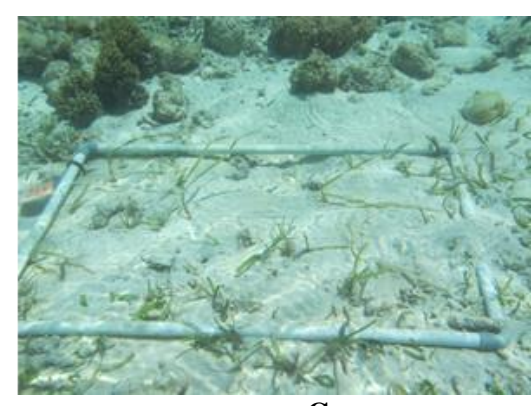

C

Figure 2. Experimental design with three treatments: A. High density and high protection treatment, B. Medium density and medium protection treatment, C. Low density and no protection treatment

\section{Data analysis}

One-way analysis of variance (ANOVA) was used to compare the growth and survival of seagrass seedlings among treatments. If the ANOVA indicated a significant difference $(p<0.05)$, a Tukey post-hoc test was conducted to identify the optimal treatment.

\section{RESULTS AND DISCUSSION}

\section{Results}

At the end of the experimental period, survival of the adult Enhalus acoroides transplants used as protectors for the young seedlings was high, for both the high density and medium density transplant treatments, with values of $83 \pm 8.9 \%$ and $93 \pm 8.9 \%$, respectively (Figure 3 ). 


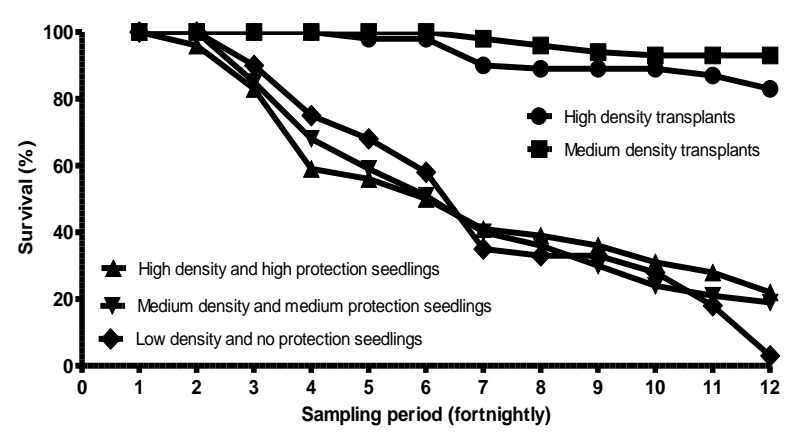

Figure 3. Survival of Enhalus acoroides seedlings in different levels of seedlings density and protection from adult transplants $($ Mean \pm SE, $n=8$ )

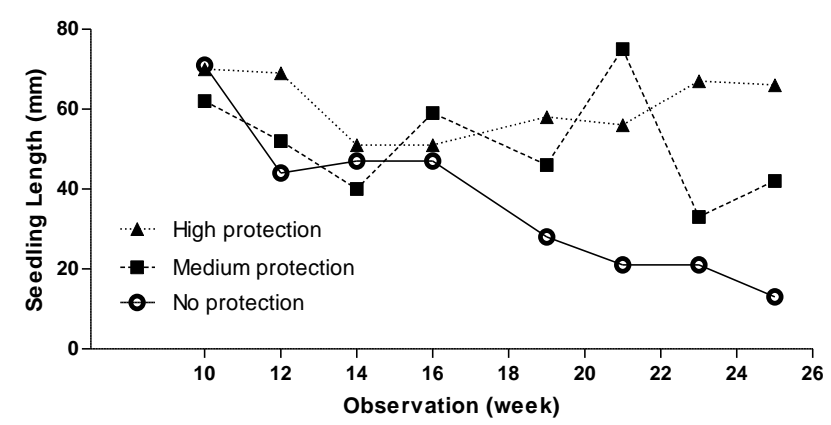

Figure 4. Average leaf length during the experiment of Enhalus acoroides seedlings in different levels of seedlings density and protection from adult transplants (Mean $\pm \mathrm{SE}, \mathrm{n}=8$ )

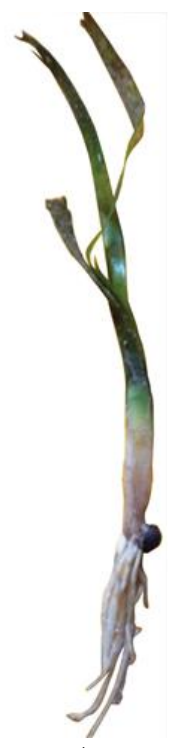

A

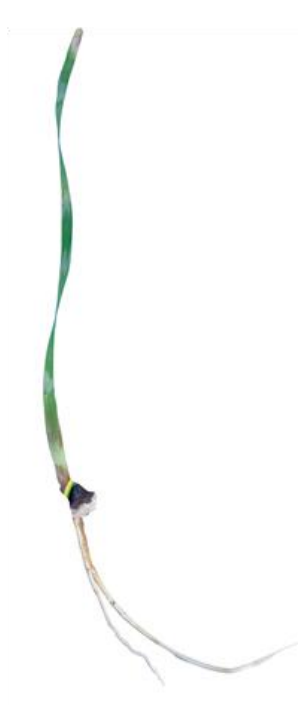

B
Figure 5. Surviving seedling ( 31 months old) compared with a 3 months old seedling (initial seedling size from the nursery before transplanted at the field)
Survival of the seedlings was high in all treatment groups during initial observations (two to four weeks; 96$100 \%$ survival). Thereafter, there was a pattern of declining in seedling survival to less than $50 \%$ after week 4 (i.e. the 2nd observation), especially from week 14 to the end of the experiment (i.e. the 7 th to the 12 th observation) in all treatments (Figure 3). Seedling survival was highest in the high density and high protection treatment (22 $\pm 4.9 \%)$, followed by the medium density and medium protection treatment $(19 \pm 4.8 \%)$, and lowest in the low density and no protection treatment $(3 \pm 2.5 \%)$.

Despite the overall decrease in survival rate overtime during the experiment, there was a significant difference between treatments in seedling survival at the end of the experiment $\left(\mathrm{F}_{2,2.1}=6.091 ; p<0.01\right)$. The seedlings with high density and high protection survived significantly better than the low-density seedlings without protection (post hoc test; $p<0.05$ ), however, survival was not significantly different for the high density and high protection seedlings vs the medium density and medium protection seedlings or for the medium density and medium protection seedlings $v s$ the low density and no protection seedlings.

The initial length of seedling leaves at the start of growth measurement ranged from 62-71 mm. Seedling leaves continued to grow throughout the experiment, but most of the leaves were also reduced in length due to grazing by herbivorous fishes, causing variations in leaf length between observations. Seedlings with high protection from the adult transplants and at higher densities maintain higher leaf growth than the other treatments (Figure 4). There was a significant difference in seedling leaf length between treatments $\left(\mathrm{F}_{2,2.1}=5.324\right.$; $\left.p<0.05\right)$; the leaves of seedlings planted at higher densities with high protection from adult grew longer compared to those of seedlings with no protection (post hoc test, $p<0.05$ ).

\section{Discussion}

Seagrass restoration has been attempted in many parts of the world, primarily through transplantation (Short et al. 2002; van Katwijk et al. 2009). Enhalus acoroides has been the main target species for seagrass restoration in Indonesia, with transplantation as the primary method used (van Katwijk et al. 2016), while few studies have focused on the use of seagrass seeds or seedlings (but see AmboRappe and Yasir 2015). Seagrass restoration using seeds or seedlings has been recommended to maintain genetic diversity and reduce damage to the donor site (Williams and Orth 1998; Orth et al. 2006b). However, it is important to provide protection to the seeds/seedlings at the restoration site, especially from wave action and substrate movement, during the early stages of the restoration process. In this study, survival of the seedlings declined until the end of experiment (over a six month period), and then began to stabilize. Such a decline in seedling survival is common in various seagrass transplantation activities, and can be considered as an adaptation stage of the seagrass propagules used as restoration agents (Fonseca et al. 1998). 
Although the experiment and routine monitoring were completed in March 2016, the plots were left in place. During a visit at the end of January 2017, we found many surviving seedlings and transplants. We sampled one seedling (Figure 5) that had become solidly anchored into the substrate through the growth of 9 roots. These roots varied from $10 \mathrm{~mm}$ to $90 \mathrm{~mm}$ in length. The seedling had also produced four new leaves $60-186 \mathrm{~mm}$ in length and 10-11 mm wide.

Survival of the seedlings planted at high density with high level of protection from adult transplants was significantly higher. The high density of adult transplants around the seedlings might function to protect the seedlings by reducing the speed of currents and the force of wave action, as suggested by Bos and van Katwijk (2007). Planting seedlings at high density may also have affected other physical factors, especially substrate movement caused by currents, considered the main factor affecting survival in seagrass restoration by van Katwijk and Hermus (2000). Artificial protectors such as various anchoring devices had been introduced in seagrass restoration project in order to enhance seagrass restoration success (Fonseca et al. 1998). In contrast, Statton et al. (2012) found a limited effect of anchoring devices on transplant survival in their review of 130 seagrass restoration project in Shark Bay and Florida Bay. However, the result of this study and with support with more positive result from other studies found the importance of providing protection to the propagules used in seagrass restoration (transplants, seeds, and/or seedlings), especially during the early stages of the restoration process, and it could be expected to enhance restoration success.

We found that combining two methods of seagrass restoration (vegetative and generative) increased the survival of seagrass seedlings; however, the success rate was also affected by seedling and transplant density. These results indicate that such adult transplants might act as important and effective protectors for the seedlings, shielding them from predators, reducing substrate movement, and mitigating the force of wave action. Higher seedling density could also enhance survival and growth; therefore seedling density should also be a consideration in generative seagrass restoration.

\section{ACKNOWLEDGEMENTS}

This research was supported by IPTEKS grant No. 048/SP2H/PL/DIT.LITABMAS/V/2015 and further data analysis by RUNAS-BOPTN 2018 grant from Hasanuddin University, Makassar, Indonesia. Finalization of the manuscript was made possible by Australia Award Fellowship R170570 and James Cook University team of Dr. Naomi Gardiner and Dr. Laurence McCook. We also thank Abigail Moore for proofreading the manuscript before submission.

\section{REFERENCES}

Alagna A, Fernandez GD, Anna C, Magliola S, Mazzola, Badalamenti F. 2015. Assessing Posidonia oceánica seedling substrate preference: An experimental determination of seedling anchorage success in rocky vs. sandy substrates. PLoS One 10 (4): e0125321. DOI: 10.1371/journal.pone.0213314

Ambo-Rappe R, Yasir I. 2015. The effect of storage condition on viability of Enhalus acoroides seedlings. Aquat Bot 127: 57-61.

Barbier EB, Hacker SD, Kennedy C, Koch EW, Stier AC, Silliman BR. 2011. The value of estuarine and coastal ecosystem services. Ecol Monogr 81: 169-193.

Bos AR, van Katwijk MM. 2007. Plant density, hydrodynamic exposure, and mussel beds affect survival of transplanted intertidal eelgrass. Mar Ecol Prog Ser 336: 121-129.

Bourque AS, Fourqurean JW. 2014. Effects of common seagrass restoration methods on ecosystem structure in subtropical seagrass meadows. Marine Environ Res 97: 67-78.

Calumpong HP, Fonseca MS. 2001. Seagrass transplantation and other seagrass restoration methods. In: Short FT, Coles RG (eds.). Global Seagrass Research Methods. Elsevier Science, Netherlands.

Cleary DFR, Renema W. 2007. Relating species traits of foraminifera to lambnakaoselig environmental variables in the Spermonde Archipelago, Indonesia. Marine Ecology Progress Series 334: 7382.

Costanza R, d'Arge R, de Groot R, Farber S, Grasso M, Hannon B, Limburg K., Naeem S, O’Neill RV, Paruelo J, Raskin RG, Sutton P, van den Belt M. 1997. The value of the world's ecosystem services and natural capital. Nature 387: 253-260.

Costanza R, de Groot R, Sutton P, van der Ploeg S, Anderson SJ, Kubiszewski I, Farber S, Turner RK. 2014. Changes in the global value of ecosystem services. Global Environ Ch 26: 152-158.

Cunha AH, Marba NN, van Katwijk MM, Pickerell C, Henriques M, Bernard G, Ferreira MA, Garcia S, Garmendia JM, Manent P. 2012. Changing paradigms in seagrass restoration. Restor Ecol 20: 427-430.

Duarte CM. 2000. Marine biodiversity and ecosystem services: an elusive link. J Exp Mar Biol Ecol 250: 117-131.

Fonseca MS, Kenworthy WJ, Thayer GW. 1998. Guidelines for the conservation and restoration of seagrasses in the United States and adjacent waters. NOAA Coastal Ocean Program Decision Analysis Series No.12. NOAA Coastal Ocean Office, Silver Spring, MD.

Kendrick GA, Waycott M, Carruthers TJB, Cambridge ML, Hovey R, Krauss SL, Lavery PS, Les DH, Lowe RJ, Vidal OM, Ooi JLS, Orth RJ, Rivers DO, Ruiz-Montoya L, Sinclair EA, Statton J, van Dijk JK, Verduin JJ. 2012. The central role of dispersal in the maintenance and persistent of seagrass populations. Bioscience 62: 56-65.

Lamb JB, van de Water JAJM, Bourne DG, Altier C, Hein MY, Fiorenza EA, Abu N, Jompa J, Harvell CD. 2017. Seagrass ecosystems reduce exposure to bacterial pathogens of humans, fishes, and invertebrates. Science 355: 731-733.

Lee K, Park JI. 2008. An effecting transplanting technique using shells for restoration of Zostera marina habitats. Mar Pollut Bull 56: 10151021.

Marion SR, Orth RJ. 2010. Innovative techniques for large-scale seagrass restoration using Zostera marina (eelgrass) seeds. Restoration Ecology 18: 514-526.

Nakaoka M. 2002. Predation on seed of seagrasses Zostera marina and Zostera caulescens by a tanaid crustacean Zeuxosp. Aquat Bot 72: 99106.

Orth RJ, Curruthers TJB, Dennison WC, Duarte CM, Fourqurean JW, Heck Jr KL, Hughes AR, Kendrick GA, Kenworthy WJ, Olyarnik S, Short FT, Waycott M, Williams SL. 2006a. A global crisis for seagrass ecosystems. BioScience 56: 987-996.

Orth RJ, Harwell MC, Inglis GJ. 2006b. Ecology of seagrasses seeds and seagrass dispersal processes. In: Larkum AWD, Orth RJ, Duarte CM (eds.) Seagrasses: Biology, Ecology and Conservation. Springer, Netherlands.

Orth RJ, Heck Jr KL, Tunbridge DJ. 2002. Predation on seeds of the seagrass Posidonia australis in Western Australia. Mar Ecol Progr Ser 244: 81-88.

Orth RJ, Kendrick GA, Marion SR. 2007. Posidonia australis seed predation in seagrass habitat of Two Peoples Bay, Western Australia. Aquat Bot 86: 83-85. 
Orth RJ, Luckenbach ML, Marion SR, Moore KA, Wilcox DJ. 2006c. Seagrass recovery in the Dermarva Coastal Bays, USA. Aquat Bot 84 26-36.

Paling EI, Fonseca M, van Katwijk MM, van KeulenM. 2009. Seagrass restoration. In: Perillo GME, Wolanski E, Cahoon DR, Brinson MM (eds.) Coastal wetlands: an integrated ecosystem approach. Elsevier, Amsterdam.

Phillips RC. 1980. Transplanting methods. In: Phillips RC, McRoy CP (eds.) Handbook of seagrass biology: an ecosystem perspective. Garland, New York.

Selig ER, Turner WR, Troëng S, Wallace BP, Halpern BS, Kaschner K, Lascelles BG, Carpenter KE, Mittermeier RA. 2014. Global priorities for marine biodiversity conservation. PLoS One 9 (1): e82898. DOI: 10.1371/journal.pone.0082898

Short FT, Davis RC, Kopp BS, Short CA, Burdick DM. 2002. Siteselection model for optimal transplantation of eelgrass Zostera marina in the northeastern US. Mar Ecol Prog Ser 227: 253-267.

Short FT, Willy-Escheverria S. 1996. Natural and human-induced disturbance of seagrasses. Environ Conserv 23: 17-27.

Statton J, Cambridge ML, Dixon KW, Kendrick WA. 2013. Aquaculture of Posidonia australis seedlings for seagrass restoration programs: effect of sediments type and organic enrichment on growth. Restor Ecol 21: 250-259.

Statton J, Dixon KW, Hovey RK, Kendrick GA. 2012. A comparative assessment of approaches and outcomes for seagrass revegetation in Shark Bay and Florida Bay. Mar Freshw Res 63: 984-993.

Thom R, Gaeckle J, Buenau K, Borde A, Vavrinec J, Aston L, Woodruff D, Khangaonkar T, Kaldy J. 2018. Eelgrass (Zostera marina L.) restoration in Puget Sound: development of a site suitability assessment process. Restor Ecol 26: 1066-1074.

Unsworth RFK, Cullen LC. 2010. Recognising the necessity for IndoPacific seagrass conservation. Conserv Lett 3: 63-73.

van Katwijk MM, Bos AR, de Jonge VN, Hanssen LSAM, Hermus DCR, de Jong DJ. 2009. Guidelines for seagrass restoration: importance of habitat selection and donor population, spreading of risks, and ecosystem engineering effects. Mar Pollut Bull 58: 179-188.

van Katwijk MM, Hermus DCR. 2000. Effects of water dynamics on Zostera marina: transplantation experiment in the intertidal Dutch Wadden Sea. Mar Ecol Prog Ser 208: 107-118.

van Katwijk MM, Thorhaug A, Marbá N, Orth RJ, Duarte CM, Kendrick GA, Althuizen IHJ, Balestri E, Bernard G, Cambridge ML. 2016. Global analysis of seagrass restoration: the importance of large-scale planting. J Appl Ecol 53: 567-578.

Waycott M, Duarte CM, Carruthers TJB, Orth RJ, Dennison WC, Olyarnik S, Calladine A, Fourqurean JW, Heck KL, Hughes AR, Kendrick GA, Kenworthy WJ, Short FT, Williams SL. 2009. Accelerating loss of seagrasses across the globe threatens coastal ecosystems. Proc Natl Acad Sci USA 106: 12377-12381.

Williams S, Orth RJ. 1998. Genetic diversity and structure of natural and transplanted eelgrass populations in the Chesapeake and Chincoteague Bays. Estuaries 21: 118-128.

Williams SL, Ambo-Rappe R, Sur C, Abbott JM, Limbong SR. 2017. Species richness accelerates marine ecosystem restoration in the Coral Triangle. Proc Natl Acad Sci USA 114 (45): 11986-11991. 